\title{
Evaluating the Use of the Activity Based Costing Method in the Construction Industry in the V4 Countries
}

\author{
Lenka Hudáková Stašová \\ Technical University of Košice, Faculty of Economics, Letná 9, Košice, Slovak Republic \\ lenka.hudakova.stasova@tuke.sk
}

Received (30-APR-2019); Revised (18-SEP-2019); Accepted (2-OCT-2019); Published online (8-OCT-2019)

\begin{abstract}
This paper evaluates the situation regarding the use of the Activity Based Costing calculation method in the sphere of industry construction in the V4 countries at the present time. The objective of the paper is to describe the strengths and weaknesses of the $A B C$ method in comparison with the traditionally used method of allocating costs, analyse the use of calculation methods in the construction industry in the Slovak Republic, the Czech Republic, Hungary and the Republic of Poland, and present recommendations on the basis of the analysis results. In the paper we describe the current trends in the construction industry, the conditions for suitability of implementation of the $A B C$ method, the possibilities of its use in company practice. The ABC method is more accurate than the traditional calculation methods, so we would recommend companies which do not have the costing method in place should consider the possibility of using the method, despite the initial high deployment costs. In companies where the overhead cost ratio is more than $40 \%$ of the total cost, the traditional costing method is not sufficient to accurately allocate indirect costs, and therefore we recommend that an $A B C$ method be used for such businesses. $A B C$ focuses mainly on the precise allocation of overheads, thus achieving an accurate tracking of the flow of costs and their causes, reducing the resources used and reducing overall costs.

We prepared our own questionnaire for analysis. The questions were answered by the company workers who do cost calculations and who are responsible for the cost calculations. The survey was conducted at company level. The total group of companies from 4 countries represented 204 companies. We also evaluated the results statistically. We focused the analysis on construction industry companies as one of the key sectors of the economy. We highlighted the benefits of the Activity Based Costing method, the study was focused on the construction industry. But similar conclusions could be applied to other industries as this method is flexible, adaptable to different environments, adaptable to different company sizes.
\end{abstract}

Key words: Activity Based Costing method, construction industry, Hungary, the Czech Republic, the Slovak Republic, Poland, traditional cost calculation

\section{INTRODUCTION}

Businesses compete with each other, especially at the level of managing activities and processes. Only those businesses that carry out their processes and activities with the highest level of quality, in the smallest amount of time and at the lowest cost have the greatest chance of surviving in the competitive battle. Thus, the value of the business necessary to satisfy the customer becomes one of the key factors of business success. The essence of cost management is in managing, re-evaluating and improving key business processes and activities. The basis for determining the processes and activities of any organization is the needs and requirements of the customer, i.e. why and for whom the organization works and what is its mission. An accurate calculation of a product or service that reflects the actual cost of a particular product is an essential piece of information necessary to manage processes. Businesses that want to succeed are focused on the effectiveness and flexibility of their own actions and processes and their optimization. One of the tools that enables it is the Activity Based Costing method (ABC).

Therefore, the paper focuses on the evaluation of the use of this method in business practice. We compare the current opinions of the authors on this method, generally evaluate its advantages, and point out the negatives. We compare the ABC method with the so-called traditional calculation method, the aim is to point out the suitability of $A B C$ method for business practice. The research has focused on the construction sector as one of the key sectors of the economy. The basis is a questionnaire survey in a set of construction companies in all V4 countries, where we find that businesses are often not informed about the possibility of cost management using other than traditional calculation methods. The goal is to bring other cost management options to the attention of managers, and to encourage consulting companies 
providing services and $A B C$ software about its need and suitability.

\section{LITERATURE REVIEW}

According to Kaplan [1], [2], [3] Activity Based Costing is an approach to solve the problems of traditional cost management systems. These traditional costing systems often can not accurately determine the actual costs of production and the costs of related services. Consequently, managers made decisions based on inaccurate data, especially when there are several products. Instead of using broad arbitrary percentages to allocate costs, $A B C$ seeks to identify cause and effect relationships to objectively assign costs. Once costs of the activities have been identified, the cost of each activity is attributed to each product to the extent that the product uses the activity. In this way ABC often identifies areas of high overhead costs per unit and so directs attention to finding ways to reduce the costs or to charge more for costly products.

Veščičík [4], [5] explains that Activity Based Costing is a new modern method of calculating the cost of individual processes, products and customers, which eliminates the inaccuracies of traditional methods of the last century (overhead calculations, covering post).

Pokorná [6] states that the search for factors that affect the efficiency of business is one of the main problems of business economists for several years. Activity-Based Costing $(A B C)$ is a management tool that provides additional and more accurate information on the costs and company performance, thus contributes to better manager decision making, and thus has potential to affect the financial performance. The ABC expansion among enterprises in the Czech Republic is currently comparable with neighbouring countries, although the extent of its use is lower.

Duh [7], Greasley, Smith, [8] argue that Activity Based Costing is an effective method not only for managing costs but also for strategic decisions. It is shown that businesses that know and optimize their processes are ready for changes caused by the external environment.

Business Process Management is an integrated system that focuses on activity-based management as a way to continuously increase customer benefits and thereby the profits of the company. It consists of three basic elements: Process Management, Cost Analysis using ABC, Balanced Scorecard. [9], [10], [11] argue that process management can affect the level of costs, profits, value added, and other attributes of the business's value-creation processes.

The $A B C$ method is the main tool. The main areas of benefits of process management are: strategic management, process re-engineering and improvement, evaluating product and customer profitability, improvement of the view of costs of the business and its functional parts [12], [13].

The prerequisites for this management method can be created using the $A B C$ method, which is a suitable tool for tracking and measuring processes [14], [15], [16].

In modern manufacturing organizations, performance measurements play an important role in providing strategic directions and developing appropriate operational policies and methods. One such method is the activity-based costing (ABC) method which calculates the cost of activities and helps in making decisions on product mix and price for improving the utilization of resources and minimizing the cost of production. Even now, some manufacturing organizations use traditional calculation methods depending on their market forces and characteristics. One of the most important decisions to be made is about the type of costing system that would be suitable for an organization. The role of direct labor in modern production environments has decreased, but at the same time, the level of support services has increased. Traditional methods of calculating the cost do not take into account this increased complexity and still distribute overhead costs by reducing their working base or even do not take into account overhead costs [17], [18].

Traditional cost accounting methods were developed at a time when direct costs of labour and material factors of production were dominant and when changes in technology and consumer demand were not so fast. The problems with traditional cost accounting emerge when indirect costs (such as maintenance, insurance, production preparation, etc.) amount to significant sums or are even higher than direct costs. Activity Based Costing is a commonly used tool and has practical significance for the specific conditions of agricultural production, where it can be used to achieve the improvement of cost management [19], [20].

Activity Based Costing represents the universal management instrument that is used not only for the purposes of cost calculations, but represents the tool enabling effective cost reduction. In addition to these advantages, the $A B C$ method has also its restriction as it is more demanding in terms of the volume and structure of the data processing. In case of its application, it is therefore necessary to consider carefully all the benefits and costs associated with its implementation [21], [22], [23].

The extensive $A B C$ use is associated with higher quality levels and greater improvements in cycle time and quality, and is indirectly associated with manufacturing cost reductions through quality and cycle time improvements. However, on average, extensive ABC use has no significant association with return on assets. Instead, weak evidence that the association between $A B C$ and accounting profitability is contingent on the plant's operational characteristics [24], [25].

Activity Based Costing system is a system that focuses on the costs of the various activities required to produce a product or service [26].

The ABC method is a progressive instrument of controlling. It enables to assign costs to products according to actually used up activities and resources. The method is designed for more accurate scheduling of indirect costs (overheads); as a schedule using the causal relationship between activities (processes) and individual performance [27].

The main principle of the $A B C$ is placing the activities among the source costs (taken over from the accountancy) and the products. One of the biggest benefits of the $A B C$ system is the interconnection of the 
costs arising from the accounting, processes and costs of products into one system [5].

Cohen [28] indicate that the possibility of future implementation of $A B C$ is related to the degree of satisfaction from the currently used cost accounting system. Companies that do not intend to adopt $A B C$ ( $A B C$ deniers) were found to be more satisfied with their existing cost accounting system in comparison to $A B C$ supporters. They also report the characteristics of companies that still have complete ignorance of the $A B C$ technique (ABC unawares).

In the last two decades, business environment has been changing rapidly with fierce global competition. Firms using the traditional costing system were forced to change from their old system traditional-cost method and to accept the newer cost system, better known as the activity based on costing (ABC system). The new system is able to support and enhance decision making of the decision makers, besides being adaptable to the new business environment [29].

In addition to these positives, it is necessary to point out the possible disadvantages of the ABC calculation method. The main disadvantage is the time-consuming nature of the method in the absence of a primary record of the necessary data. This may mean that management focuses more on obtaining the necessary cost data for each activity rather than on improvement of these activities. Obtaining information is an additional cost for the organization [30].

It is important to note that $A B C$ is only one method for allocating indirect costs, it does not reduce production costs (material or labour costs), but it helps management to understand which products consume the most resources, and therefore this method gives options for informed decision making. The ABC method focuses only on corporate overhead, capital costs are not taken into account [31].

The objectives of the paper are to describe the strengths and weaknesses of the ABC method in comparison with the traditionally used method of allocation costs, analyse the use of calculation methods in the construction industry in all V4 countries, as well as present recommendations on the basis of the results of analysis, to get the $A B C$ method into the awareness of company managers as a suitable alternative to the obsolete socalled traditional calculation methods.

For the analysis, we chose the construction industry, which is one of the key industries. In Slovakia, it creates around $7 \%$ of all jobs in the country. In the countries of the European Union, construction currently accounts for $9 \%$ to $10 \%$ of GDP, representing a quarter of the total output of European industries.

Based on the above, we have identified research questions:

What types of calculation methods are used by construction companies today?

What are the advantages, resp. disadvantages of $A B C$ method in practice?
How many companies in the construction industry know the $A B C$ method and how many companies actually use it?

\section{MATERIALS AND METHODS}

\subsection{Sample and data collection procedure}

In order to fulfil the objectives of this paper, we compiled a set of companies active in the construction industry in each country, divided the businesses into groups by size (by number of employees) and analysed the use of the ABC method for each group. In the Slovak Republic, the analysed set contained 56 businesses, 52 in the Czech Republic, 47 in Hungary, and 49 in the Republic of Poland.

For the purposes of analysing and discovering the use of calculation methods in individual businesses, we developed a questionnaire with the following questions: 1. What is the size of your business by number of employees (0-9 employees, 10-49 employees, 50-249 employees);

2. Questions about usage of the Activity Based Costing method in business practice with following answers:

- we do not know the method,

- we know the method, but we decided not to use it,

- we are currently introducing the method,

- we already use the method,

- $\quad$ we used the method but it was not successful); 3. Why you do not use the ABC method when it knows about it?

4. How long have you been using the $A B C$ method?

5. Has the ABC met your expectations?

6. Why the method was not successful (among companies that used it and stopped using it)?

The results obtained are presented in tables and graphs.

The research sample is a selected group of companies in the construction industry with comparable representation from all V4 countries - 204 enterprises in total. The questionnaire questions were answered by employees who are responsible for cost calculations in the company. The survey was conducted at the company level.

Question 1 from the questionnaire is evaluated in the analytical part using a table and a graph.

The results of question 2 from the questionnaire are processed in the tables, namely the counts are mentioned, expected counts are calculated, and pivot tables are used, as well as a table of percentages. In addition, all answers from question 2 are shown by graphs.

The results and findings of the other questions from the questionnaire are described in the text.

In addition to this analysis, we also presented an example of a cost calculation in a construction company using the traditional cost allocation method and at the same time using $A B C$.

\subsection{Characteristics of calculation methods}


Costs in the calculation system can be determined using the traditional cost allocation method based on the direct and indirect cost breakdowns: direct costs are added directly to the actual output, indirect costs are charged primarily to economic centres and then allocated to individual outputs. Using the ABC method, direct costs are added to cost objects directly (as with the cost allocation method), indirect costs are attributed to activities. Thus, in the area of direct costs, the ABC method does not bring about any change, its substantial contribution is to the allocation of indirect costs.

In theoretical works, Activity Based Costing (ABC) is a method of cost calculating referred to as new, modern. It allocates the costs to individual processes, products and customers, eliminates the inaccuracies of traditional methods from the past century (overhead calculations, cover contribution).

It provides reliable information for both strategic and operational decisions, as it shows the causal relationship between the origination of costs in the business and revenues from sale to the customers.

The main principle of the $A B C$ is the "insertion" of activities between the costs of resources (bookkeeping) and products (Figure 1). In this way, a logical link is established between costs by type and activity on the one hand (each cost is incurred by an activity) and the relationship between the costs of activities and the products (the costs of the product equal to the sum of the parts of the costs of the activities required for its manufacture-e.g. procurement of supplies, production, sales, etc.), on the other hand.
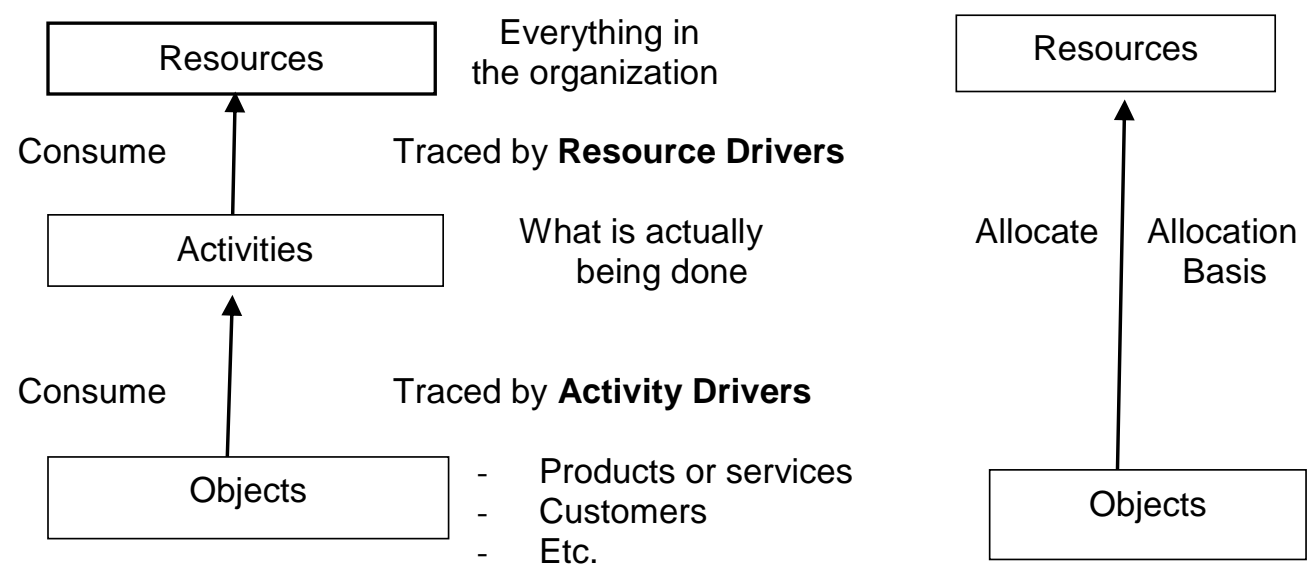

- Products
- Services

Figure 1. Activity based costing vs. traditional methods

Traditional method of preparing the calculation (overhead calculation - absorption costing) is a traditional, less demanding calculation, still used in many manufacturing and non-manufacturing businesses. It is used in enterprises where different kinds of products with varying production costs are produced in various technological processes. Its principle is to allocate direct costs (directly logically attributable to products, orders, or services provided), and the remaining indirect costs (overheads), which are calculated as mark-ups (or overhead rates) in the calculation formula.

One identical (common) budgetary base is selected for all types of production overhead costs, and equally, one identical budgetary base is selected for all types of administrative overhead costs.

The mark-up method is suitable for smaller, simpler and less dynamic businesses with low indirect costs. This traditional cost allocation method, that allocates overheads to a unit of production based on labour or machine hours, often leads to incorrect unit costs: for example, large overhead costs are disproportionately allocated to large volume products produced in large batches and conversely, too little of the overhead costs is allocated to low-volume items.

Activity Based Costing helps to eliminate this problem by allocating overheads to products depending on the extent to which these products contribute to the overhead costs.

\section{RESULTS AND DISCUSSION}

\subsection{The importance of measuring human capital and investment to human resource development}

In the construction industry, the two methods of calculation are most commonly used - the traditional cost allocation and $A B C$ methods. In the case of the traditional cost allocation method, the relationship between outputs and their varying intensity of consumption of resources and the activities of the business is lost. By contrast, the ABC method monitors use of costs for specific outputs in relation to individual business activities. In the traditional cost allocation method for assigning costs to outputs, we see that the business's cost information is broken down by centres and outputs, under ABC it is by activity (activity). Indirect performance costs are, in fact, directly related to processes. The processes necessary to create a concrete result lead to an increase in costs, which makes them more complex and numerous. While we try to find out the relationship between production and consumption of resources in the traditional method, $A B C$ is concerned about the causal relationship between 
processes and resource consumption. Thus, processes generate costs and individual outputs consume these processes.

From the point of view of the traditional cost allocation method, we monitor the yields and costs in the economic centres, as well as their economic results. By contrast, in the $A B C$ method and its cost centres, we compare real costs with planned costs, resulting in a difference between these data. For $A B C$, we need to adjust cost tracking by concentrating it into cost pools. These cost pools have the task of capturing costs according to the whole and according to aggregated activities. The traditional method assigns overheads to individual centres, while the $A B C$ calculation systems assign overheads to each major activity rather than individual centres.

The ABC method assigns costs to products and services and other cost items from the cost pools of activities by using the allocation base of the appropriate support costs of activities. The traditional method assigns costs to products by using an allocation base based on the number of units, direct labour costs, machine hours, and so on.

The $A B C$ method requires high entry costs for both introduction and maintenance, whereas the traditional method is undemanding in terms of introduction and maintenance. The $A B C$ method gives more accurate calculation of the cost of individual outputs, while under the traditional method the cost of the products is accurate throughout the business, but they are not correctly assigned to each output. The $A B C$ method requires an accurate distinction between product value-adding activities and other activities not adding external or internal value; the traditional method does not distinguish costs adding value from costs not adding value to the product.

According to the International Association of Financial Executives Institutes (IAFEI, 2016) 10\% of companies in the construction industry worldwide use the $A B C$ method. In 2016, 31\% of companies combined the methods of Benchmark, ABC and Balanced Scorecard. Several CFOs were invited to comment on $A B C / A B M$. The CFOs indicated that this alternative cost allocation method is being used as a result of the increasing proportion of indirect costs in total costs. They confirmed that the $A B C / A B M$ method is a solution to improve the understanding of cost-creating mechanisms.

\subsection{Analysis of the Advantages and Disadvantages of the Calculation Methods}

To better compare the advantages and disadvantages of both methods, we give an example of cost calculation based on the traditional method and the ABC method in a construction business - cost calculation for $1 \mathrm{~m} 3$ of perimeter masonry of from POROTHERM $44 \times 25 \times 23.8$ bricks.

\section{Calculation of costs by the traditional method:}

Direct material. 105.46

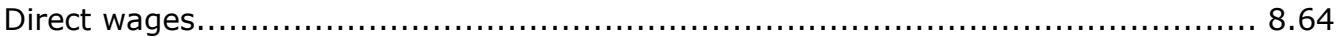

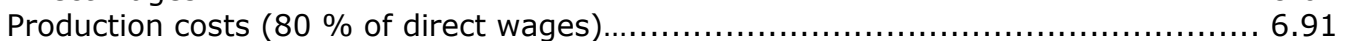

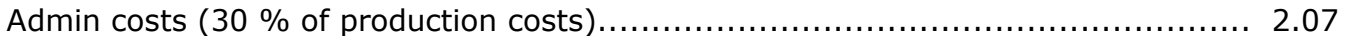

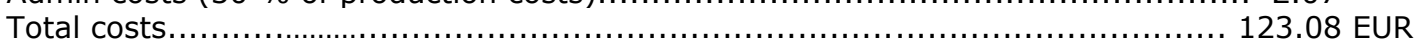

\section{Calculation of costs using the ABC method:}

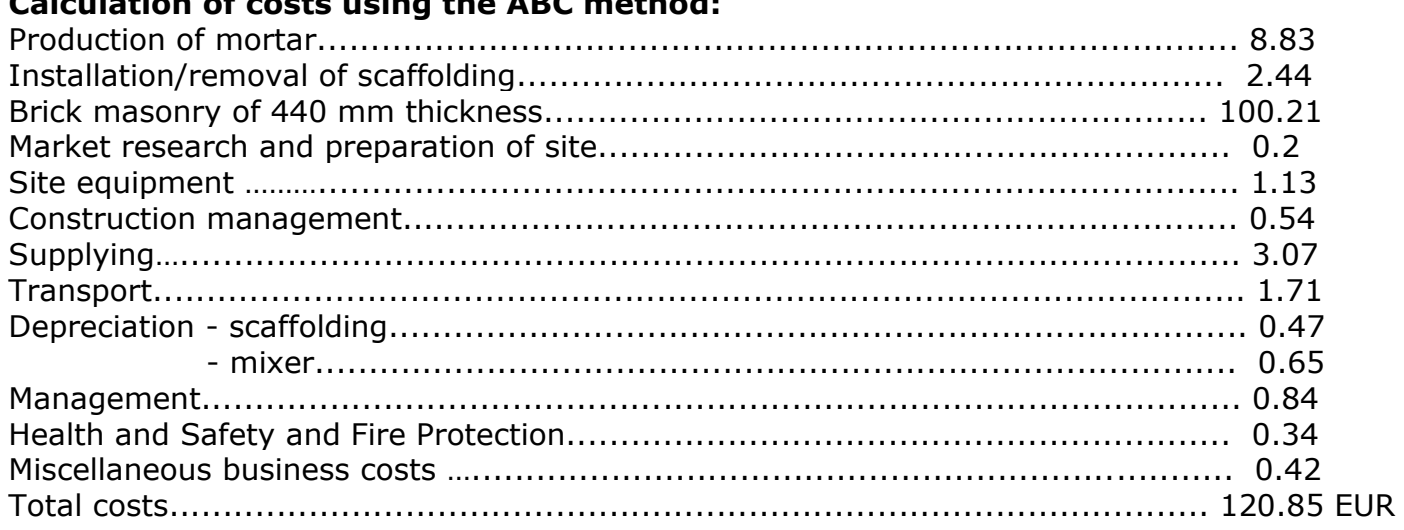

Difference between costs calculated using the traditional and $A B C$ methods:

Total costs determined using traditional method............... 123.08 EUR/1 m3 of masonry

Total costs determined using ABC method..................... 120.85 EUR/1 m3 of masonry

Difference between methods........................................ $2.23 \mathrm{EUR} / 1 \mathrm{~m} 3$ of masonry

Figure 2. Calculation of costs using the traditional method compared to the ABC method

The main shortcoming of the traditional method is that the processes (activities) that are not involved in the creation of the given output are also attributed through the overhead to the total cost of the output (product). This leads to assigning costs to outputs which are not 
responsible for them. A significant part of the costs are overheads, which are allocated to the individual outputs using an allocation base. Most often, problems arise from an inappropriately determined allocation base and hence also from an imprecise calculation of the overhead for the costing units.

By contrast, the main benefit of the $A B C$ method is the precise allocation of overhead costs to a costing unit in a business using advanced manufacturing technologies, given the high share of overheads in total costs, with a larger share of overhead costs directly attributable to outputs. The ABC method considers the cause of the cost to be an activity rather than production, thus improving the way in which the overhead costs are attributed to outputs with more accurate and reliable calculation of the full total costs. The ABC method gives more accurate information about the costs of partactivities in the business. It is flexible because, besides performance costs, it assigns costs to processes, customers, etc., it provides more accurate information for managers in decision-making and planning through activity and capacity management instead of resource management. It is highly probable that the opportunity to reduce costs is found when we achieve the same result at lower costs or find opportunities to increase profits.

The information provided by the ABC method does not only serve for one-time substantial changes (reengineering) but also for slower but lasting changes in the company. The ABC method works as a tool by which the organization and its employees can better understand how their business works, the cause and effect of certain activities, logically showing how the costs flow from resources through activities to cost objects (outputs).

However, the ABC method does not have only benefits. Its main shortcomings are that it establishes numerous cost pools and, together with cost drivers, multiplying the data on costs, which raises the need for a large amount of input and output data disproportionately burdening the administrative apparatus. The method is not applicable or suitable for all types of businesses. It has high demands on the skills and experience of workers during its introduction and causes changes in the current way of conducting in-house accounting. Businesses lack experience of deploying it and it also requires high financial demands for additional work, new way of recording, software, employee training, and so on. We are not just talking about the financial costs that are available from normal accounting, but also about hidden costs, i.e. the cost of time and effort of many workers in various business activities. Excessive investments can threaten the business.

The main disadvantage is the high degree of complexity of the volume and detail of the surveyed data, the discrepancy of the method for enterprises with a low share of overhead in total costs. ABC calculations are aimed at detailed and complicated costing, requiring change of approach to data and specialized software. This means that introducing this method for the business is primarily a major burden, whether material, financial or in terms of work.

\subsection{Use of the $A B C$ Method in the Construction Industry in the V4 Countries at Present}

The analysed set of businesses in the construction industry were first divided into size groups (by number of employees) in all V4 countries. We used the results of the questionnaire, described in more detail in the methodical section of the paper.

Table 1. Distribution of firms by country and size

\begin{tabular}{|c|c|c|c|}
\hline Country & $0-9$ employees & 10-49 employees & 50-249 employees \\
\hline The Slovak Republic & $13,72 \%$ & $9,31 \%$ & $4,41 \%$ \\
\hline The Czech Republic & $14,22 \%$ & $7,35 \%$ & $3,92 \%$ \\
\hline Hungary & $6,86 \%$ & $10,29 \%$ & $5,89 \%$ \\
\hline The Republic of Poland & $3,43 \%$ & $15,69 \%$ & $4,91 \%$ \\
\hline Precentage total & $38,23 \%$ & $42.64 \%$ & $19,13 \%$ \\
\hline
\end{tabular}

Source: Own table

All enterprises included in the research were 204 (of which in SR - 56, CZ - 52, HU - 47 and PL - 49). The group of small enterprises (0-9 emploees) represented $38.23 \%$ of all enterprises, the group of medium

enterprises (10-49 emloyees) represented $42.64 \%$ and the group of large enterprises (50-249 employees) $19.13 \%$. 


\section{Companies by size}

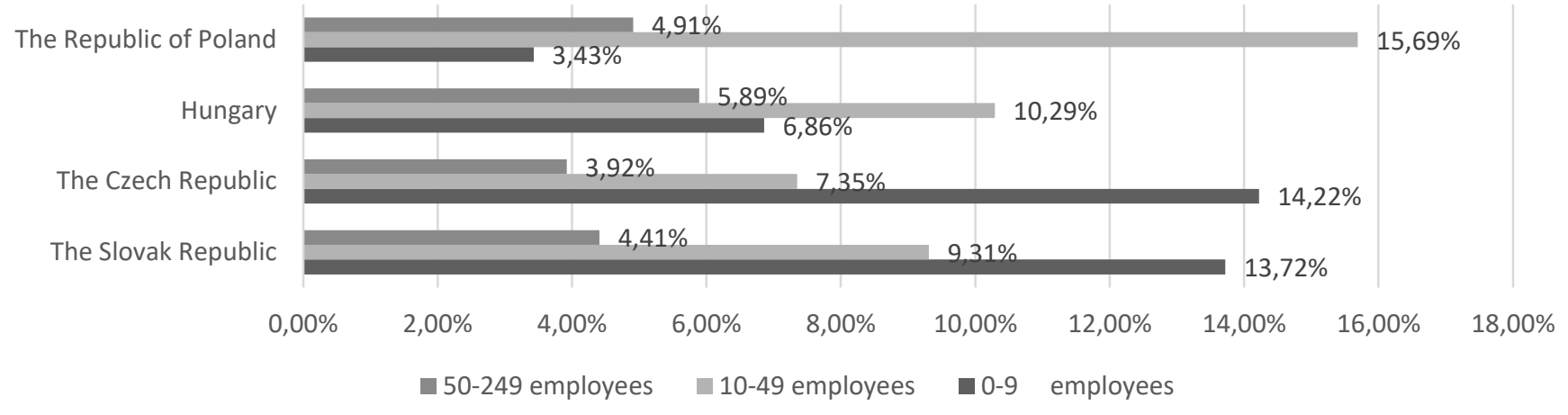

Source: own graph

Figure 3. Number of analysed businesses by size in V4 countries

Most of the businesses in the survey were in the second size category (43\%), the largest group of respondents in the Republic of Poland and Hungary. The second largest group was businesses with a number of employees from
0 to $9(38 \%)$. In the Slovak Republic and the Czech Republic, these companies represented the largest share of the total number of respondents.

Table 2. Use of the Activity Based Costing method by businesses in the construction industry in the V4 countries the table of count

\begin{tabular}{|c|c|c|c|c|c|c|c|c|c|c|c|c|}
\hline \multirow[t]{3}{*}{ Answers } & \multicolumn{12}{|c|}{ Number of businesses by size } \\
\hline & \multicolumn{4}{|c|}{ 0-9 employees } & \multicolumn{4}{|c|}{ 10-49 employees } & \multicolumn{4}{|c|}{ 50-249 employees } \\
\hline & SK & $\mathrm{CZ}$ & $\mathrm{HU}$ & $\mathrm{PL}$ & SK & $\mathrm{CZ}$ & $\mathrm{HU}$ & $\mathrm{PL}$ & SK & $\mathrm{CZ}$ & $\mathrm{HU}$ & $\mathrm{PL}$ \\
\hline Do not know about the method & 11 & 11 & 8 & 3 & 9 & 2 & 7 & 14 & 2 & 1 & 0 & 3 \\
\hline $\begin{array}{l}\text { Do know about the method, but do not } \\
\text { use }\end{array}$ & 3 & 5 & 1 & 2 & 5 & 3 & 3 & 7 & 1 & 1 & 4 & 2 \\
\hline Currently introducing & 5 & 5 & 3 & 1 & 0 & 3 & 5 & 4 & 2 & 2 & 3 & 0 \\
\hline Use the method & 7 & 7 & 2 & 1 & 6 & 7 & 6 & 5 & 4 & 4 & 5 & 4 \\
\hline $\begin{array}{l}\text { Tried the method, but it was not } \\
\text { successful for them }\end{array}$ & 2 & 1 & 0 & 0 & 0 & 0 & 0 & 2 & 0 & 0 & 0 & 1 \\
\hline Total & 28 & 29 & 14 & 7 & 19 & 15 & 21 & 32 & 9 & 8 & 12 & 10 \\
\hline
\end{tabular}

Source: Own table 
Table 3. Use of the Activity Based Costing method by businesses in the construction industry in the V4 countries the table of expected count

\begin{tabular}{|c|c|c|c|c|c|c|c|c|c|c|c|c|}
\hline \multirow[t]{3}{*}{ Answers } & \multicolumn{12}{|c|}{ Number of businesses by size } \\
\hline & \multicolumn{4}{|c|}{ 0-9 employees } & \multicolumn{4}{|c|}{ 10-49 employees } & \multicolumn{4}{|c|}{ 50-249 employees } \\
\hline & SK & $\mathrm{CZ}$ & $\mathrm{HU}$ & $\mathrm{PL}$ & SK & $\mathrm{CZ}$ & $\mathrm{HU}$ & $\overline{P L}$ & SK & $\overline{C Z}$ & $\mathrm{HU}$ & $\overline{\mathrm{PL}}$ \\
\hline Do not know about the method & 11,0 & 7,8 & 4,5 & 2,9 & 7,5 & 4,0 & 6,7 & 13,1 & 3,5 & 2,2 & 3,8 & 4,1 \\
\hline $\begin{array}{l}\text { Do know about the method, but do not } \\
\text { use }\end{array}$ & 4,5 & 5,0 & 2,4 & 1,6 & 3,1 & 2,6 & 3,6 & 7,2 & 1,4 & 1,4 & 2,0 & 2,2 \\
\hline Currently introducing & 3,5 & 5,6 & 3,3 & 0,7 & 2,4 & 2,9 & 4,9 & 3,3 & 1,1 & 1,5 & 2,8 & 1,0 \\
\hline Use the method & 8,0 & 10,0 & 3,9 & 1,4 & 5,4 & 5,2 & 5,8 & 6,5 & 2,6 & 2,8 & 3,3 & 2,0 \\
\hline $\begin{array}{l}\text { Tried the method, but it was not } \\
\text { successful for them }\end{array}$ & 1,0 & 0,6 & 0,0 & 0,4 & 0,7 & 0,3 & 0,0 & 2,0 & 0,3 & 0,2 & 0,0 & 0,6 \\
\hline Total & 28,0 & 29,0 & 14,0 & 7,0 & 19,0 & 15,0 & 21,0 & 32,0 & 9,0 & 8,0 & 12,0 & 10,0 \\
\hline
\end{tabular}

Source: Own table

Table 4. Use of the Activity Based Costing method by businesses in the construction industry in the V4 countries in percentage of total

\begin{tabular}{|c|c|c|c|c|c|c|c|c|c|c|c|c|}
\hline \multirow[t]{3}{*}{ Answers } & \multicolumn{12}{|c|}{ Number of businesses by size } \\
\hline & \multicolumn{4}{|c|}{ 0-9 employees } & \multicolumn{4}{|c|}{ 10-49 employees } & \multicolumn{4}{|c|}{ 50-249 employees } \\
\hline & SK & $\mathrm{CZ}$ & $\mathrm{HU}$ & $\mathrm{PL}$ & SK & $\mathrm{CZ}$ & $\mathrm{HU}$ & $\mathrm{PL}$ & SK & $\mathrm{CZ}$ & $\mathrm{HU}$ & $\mathrm{PL}$ \\
\hline $\begin{array}{l}\text { Do not know about } \\
\text { the method }\end{array}$ & $19,6 \%$ & $21,2 \%$ & $17,0 \%$ & $6,1 \%$ & $16,1 \%$ & $3,8 \%$ & $14,9 \%$ & $28,6 \%$ & $3,6 \%$ & $1,9 \%$ & $0,0 \%$ & $6,1 \%$ \\
\hline $\begin{array}{l}\text { Do know about the } \\
\text { method, but do not } \\
\text { use }\end{array}$ & $5,4 \%$ & $9,6 \%$ & $2,1 \%$ & $4,1 \%$ & $8,9 \%$ & $5,8 \%$ & $6,4 \%$ & $14,3 \%$ & $1,8 \%$ & $1,9 \%$ & $8,5 \%$ & $4,1 \%$ \\
\hline $\begin{array}{l}\text { Currently } \\
\text { introducing }\end{array}$ & $8,9 \%$ & $9,6 \%$ & $6,4 \%$ & $2,0 \%$ & $0,0 \%$ & $5,8 \%$ & $10,6 \%$ & $8,2 \%$ & $3,6 \%$ & $3,8 \%$ & $6,4 \%$ & $0,0 \%$ \\
\hline Use the method & $12,5 \%$ & $13,5 \%$ & $4,3 \%$ & $2,0 \%$ & $8,9 \%$ & $13,5 \%$ & $12,8 \%$ & $10,2 \%$ & $7,1 \%$ & $7,7 \%$ & $10,6 \%$ & $8,2 \%$ \\
\hline $\begin{array}{l}\text { Tried the method, } \\
\text { but it was not } \\
\text { successful for them }\end{array}$ & $3,6 \%$ & $1,9 \%$ & $0,0 \%$ & $0,0 \%$ & $0,0 \%$ & $0,0 \%$ & $0,0 \%$ & $4,1 \%$ & $0,0 \%$ & $0,0 \%$ & $0,0 \%$ & $2,0 \%$ \\
\hline Total & $50,0 \%$ & $55,8 \%$ & $29,8 \%$ & $14,3 \%$ & $33,9 \%$ & $28,8 \%$ & $44,7 \%$ & $65,3 \%$ & $16,1 \%$ & $15,4 \%$ & $25,5 \%$ & $20,4 \%$ \\
\hline
\end{tabular}

Source: Own table

Table 2 shows the numbers of enterprises in absolute value by questionnaire question (broken down by 5 answers to question 2). For a more in-depth statistical analysis, Table 3 shows the expected counts (using pivot tables). Table 4 shows answers in the percentage. Table 4 is followed by Chart 3 , regarding the answers to question 2. 


\section{Do not know about the method}

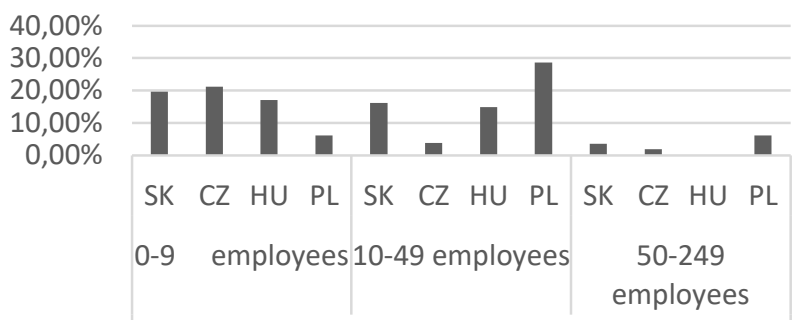

Number of businesses by size

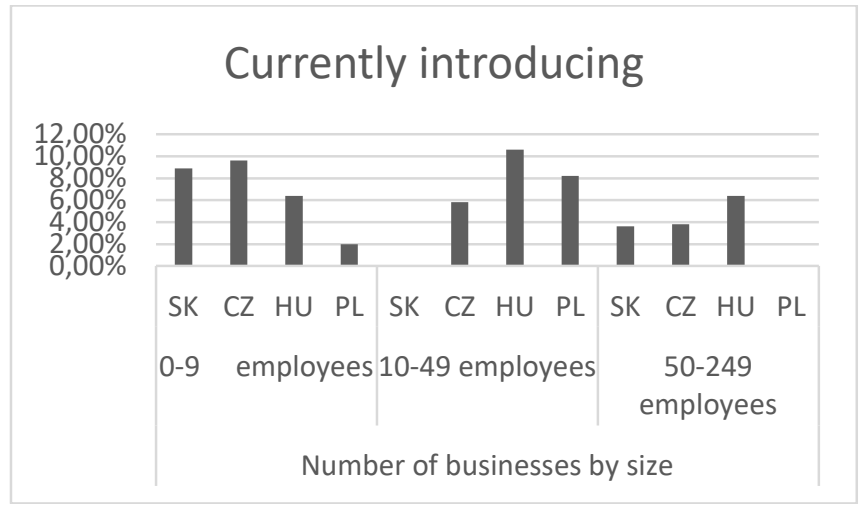

Tried the method, but it was not successful for them

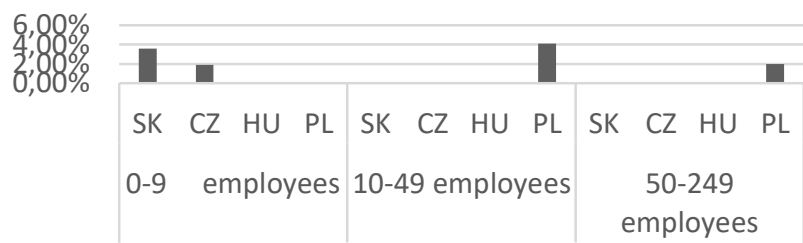

Number of businesses by size

Based on the analysis of the selected companies operating on the Slovak market, we found that as many as 22 businesses (39\%) do not know about the ABC method. On the other hand, up to 17 businesses (30\%) use the Activity Based Costing method and another 7 $(12.5 \%)$ are currently introducing the method. Only two companies said they tried the $A B C$ method, but it was not successful. Nine companies (16\% of all respondents) know the method, but have decided not to use it.

The largest share of Slovak companies, which said that they did not know the ABC method, are companies with a number of $0-9$ employees. By contrast, only $4 \%$ of large businesses do not know about this calculation method. Only small businesses up to 9 employees said they tried the method, but it was not successful for them.
Do know about the method, but do not use

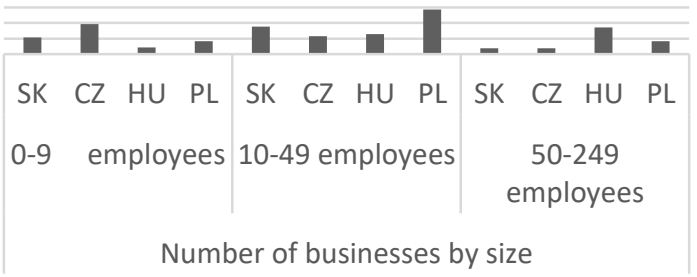

Source: Own graphs

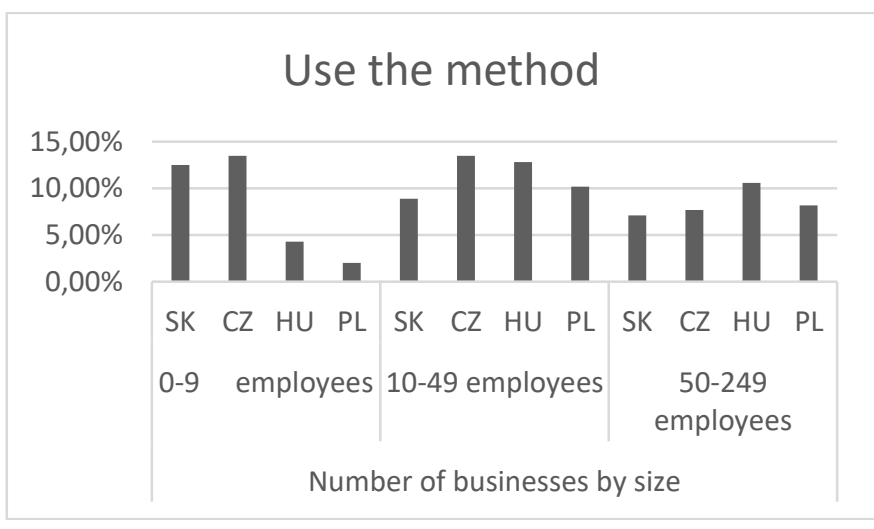

Figure 3. Use of the Activity Based Costing method by questionnaire answers

In the Czech Republic, almost $35 \%$ of the companies surveyed in the construction industry use the $A B C$ method, of which 7 were small, 7 were medium-sized and 4 were large companies. The second largest group $(27 \%)$ were companies that did not know about the method.

The results obtained in Hungary showed, as in other countries, that many companies (32\%) do not know the $A B C$ method. However, this was true only of mediumsized and small companies and not of even one large company. On the other hand, the percentage of businesses using the method is high - $27.5 \%$ of businesses use the method and another $23.5 \%$ are currently introducing it. None of the companies in this country indicated that they tried the calculation method, but without success, which indicates that Hungarian 
companies that have implemented the $A B C$ method are also satisfied with it.

In the Republic of Poland, up to $41 \%$ of businesses said they did not know the ABC method, with companies of 10 to 49 employees representing the largest share. That said, $22.5 \%$ of businesses said they knew about the method but did not use it. 10\% of Polish companies in the construction industry are currently introducing the

\section{The Slovak republic}

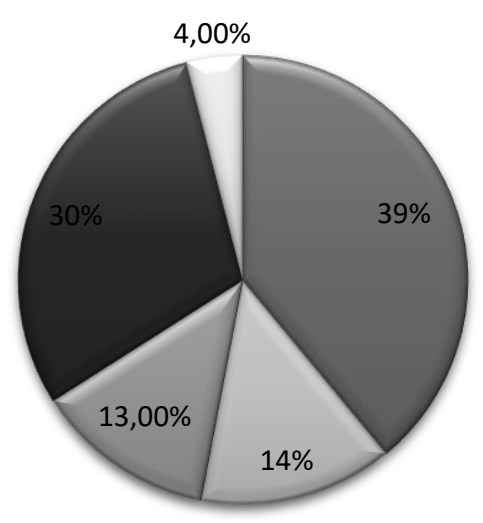

\section{Hungary}

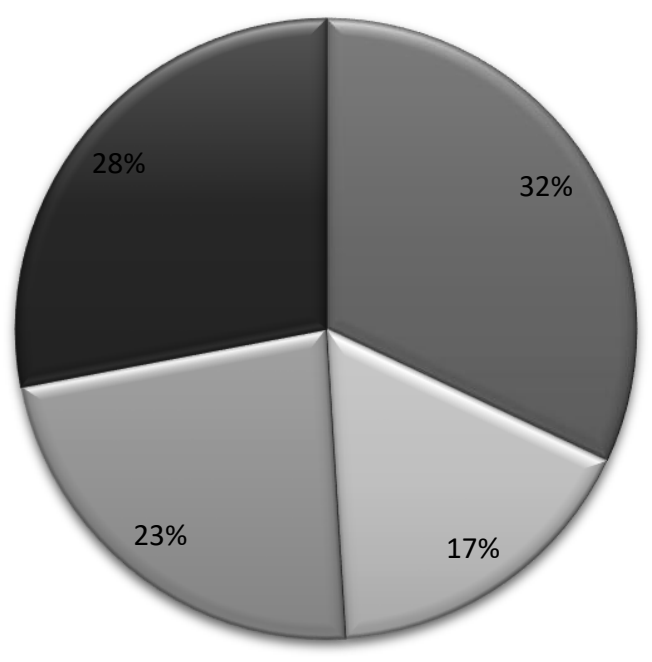

method, specifically small and medium-sized businesses. Among the large surveyed companies, none of the methods currently applied. In the Republic of Poland $20 \%$ of businesses are currently using the method.

\section{The Czech Republik}

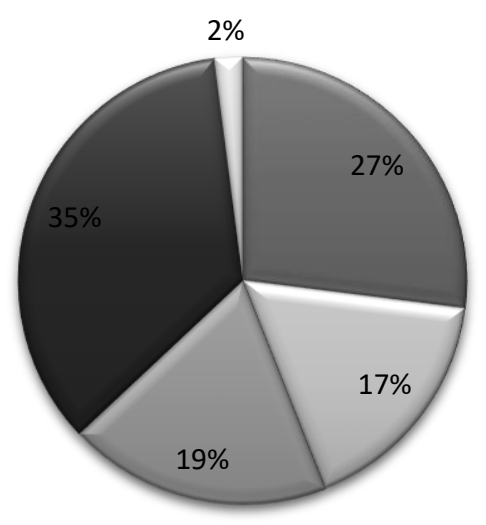

\section{The Republic of} Poland

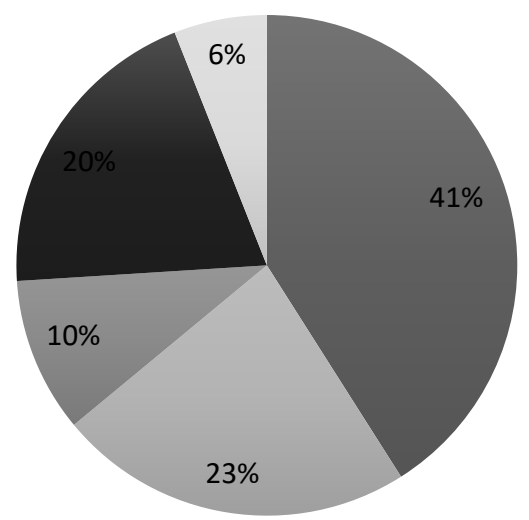

do not know of the method

do know of the method, but do not use

w currently introducing

use the method

tried the method, but it was not successful for them

Source: Own graphs

Figure 4. Use of the Activity Based Costing method in percentages in every country 
Based on the results obtained, we note that the $A B C$ method is quite often used by the companies in the V4 countries. Every business surveyed had the opportunity to comment and clarify why they chose the ABC method. The most common responses were to increase business competitiveness, control business processes, increase efficiency, reduce costs, improve and simplify management, manage cost efficiently, increase flexibility of performance, productivity, flexibility, reduce storage costs. These responses largely correspond to the aforementioned advantages of the ABC method.

Companies that stated they use this method also responded to the next question about the length of use of Activity Based Costing. The most common responses were 2 to 4 years, and none of the companies have been using the method for more than 5 years. Businesses using the method have said that they have the same benefits in practice as we stated in analysing the strengths of the $A B C$ method, but they also stated that the implementation of the method was very demanding both in time and in financial terms. They stated that in some cases it took a long time for employees and business management to gain a command of the method.

Conversely, the most common answers to the question of why companies opted not to use it were similar to the generally recognized shortcomings and weaknesses of the $A B C$ method. Businesses said that introducing such a costing method is very demanding both financially and in time. In most cases, they encountered the reluctance of management and staff to introduce new procedures with insufficient expertise of the workers who would use the method. In particular, small companies are reluctant to use this method precisely because of the lack of a truly skilled workforce that will start using it. Large companies with more than 50 employees had less problems with unskilled employees. These businesses have often said that instead of using $A B C$ methods, they use other traditional or non-traditional methods of calculating costs that have worked well for them or they do not have to make efforts to apply new methods.

Businesses that stated they know the ABC method, but chose not to use it, use a different costing method. Most commonly, traditional methods such as traditional cost allocation (using an allocation base), the simple division method, or an internal method developed by internal programmers.

The results of the analysis showed that companies in the V4 countries are very often not informed about the possibility of cost management using other than traditional calculation methods. As in almost every country the largest proportion of companies were those who had not encountered the $A B C$ method or had no further information on how to use this costing method, we encourage companies providing $A B C$ services and software to start informing firms more about this possibility by distributing prospectuses, physical company visits, and organizing various training sessions. The $A B C$ method is more accurate than the traditional calculation methods, so we would recommend companies which do not have the costing method in place should consider the possibility of using the method, despite the initial high deployment costs.

The use of $A B C$ in business practice can take two forms: a one-time model - e.g. a strategic ABC model, or as an operational model for regular monthly or quarterly evaluations that are part of the ordinary controlling process.

A one-time model serves to analyse the selected period or part of the business (processes, products, customers) in order to examine the necessary connections. The typical example is the calculation of the resulting calculations for products during the selected period. In the one-time model, ABC data connections with other data sources (IS modules) need not be addressed and targeted simplification is used that does not have a significant effect on the result. One-time $A B C$ models can be used for resulting calculations, what-if analysis, occasional process optimization, product or customer portfolio, strategic ABC models and strategic planning.

Operational models for regular monthly or quarterly evaluations are suitable for businesses with dynamically changing conditions (prices, discounts, quantities produced, input costs). Here, as a rule, monthly calculations are required, it is necessary to systemically address the connection of $\mathrm{ABC}$ with primary records in the information system modules. The model produced must be detailed to take into account the specificities of the costs and their causes. Monthly calculations are performed in specialized software (e.g. MonetABC), which is an extension to the transaction system and is generally linked to data exports and imports. Implementation of an operational model takes longer because it is usually an attempt to maximize the automation of monthly calculations. Operational ABC models are used for monthly results calculations, support for employee motivation to keep track of process costs, ongoing process optimization, product and customer portfolios, business negotiation support.

\section{CONCLUSION}

The current trend in the construction industry is the streamlining of own production. In particular, businesses focus on the strengths of their manufacturing activity and stop doing the construction work which they can buy cheaper and better from a third party (subcontractor outsourcing). Subcontracting activities such as: selecting optimal subcontractors, planning and organizing subcontracting, subcontracting directly on site and control also increase overheads, thereby increasing the share of overheads and, conversely, the share of direct costs decreases relatively.

In companies where the overhead cost ratio is more than $40 \%$ of the total cost, the above-mentioned traditional costing method is not sufficient to accurately allocate indirect costs, and therefore we recommend that an $A B C$ method be used for such businesses. ABC focuses mainly on the precise allocation of overheads, thus achieving an accurate tracking of the flow of costs and their causes, reducing the resources used and reducing overall costs.

The suitability of the application of the ABC method in a particular business can be judged on the basis of the 
fulfilment of the basic criteria: a high volume of overheads (overhead costs must account for at least 40$50 \%$ of total costs), a high number of diverse outputs, a large number of customers, high degree of automation of production, high number of different business activities, high proportion of auxiliary, support and servicing activities. The decisive question of whether or not to implement the $A B C$ method is the return on resources invested in this change. Since the $A B C$ method is a change of view and thinking, the quantification of returns is very difficult. And precisely the suitability of introducing the $A B C$ method for specific companies could be the focus of further research. It would be beneficial to analyze and propose criteria for how a company can determine if a method is appropriate and beneficial for it.

\section{REFERENCES}

[1] Kaplan, R.S., Aderson, S.R. (2003), "Time-Driven Activity-Based Costing" Available at: http://nliah.com/Portal/microsites/Uploads/Resources/o1NEDPiV g.pdf [Accessed: 2019, april 10]

[2] Kaplan, R.S., Aderson, S.R. (2005), "Rethinking Activity-Based Costing - HBS Working Knowledge." Available at: http://hbswk.hbs.edu/item/4587.html [Accessed: 2019, april 10]

[3] Kaplan, R.S., Aderson, S.R. (2007). Time - Driven Activity - Based Costing. Boston: Harvard Business School Press

[4] Veščičík M. (2004), "The successful introduction of Activity Based Costing (Predpoklady úspešného zavedenia Activity Based Costing)" Available http://www.gradient5.sk/download/Predpoklady\%20zavedenia\% 20ABC.pdf [Accessed: 2018, november 10]

[5] Veščičík, M. (2012), "By inaccurate overheads to addressable process costs. (Od nepresných réžii $k$ adresným nákladom procesov.)", Financial Management - Controlling Section (Finančný manažment - rubrika controlling), Vol. 10, Wolters Kluwer

[6] Pokorná, J. (2016), "Impact of Activity-Based Costing on Financial Performance in the Czech Republic", Acta Universitatis Agriculturae et Silviculturae Mendelianae Brunensis, Vol. 64, No. 2, pp. 643-652

[7] Duh, R.-R., Lin, T., W., Wang, W.-Y., Huang, Ch.-H. (2009), "The design and implementation of activity-based costing: $A$ case study of a Taiwanese textile company", International Journal of Accounting \& Information Management, Vol. 17, No. 1, pp. 2752. https://doi.org/10.1108/18347640910967726

[8] Greasley, A., Smith, C., M. (2017), "Using activity-based costing and simulation to reduce cost at a police communications centre", Policing: An International Journal of Police Strategies \& Management, Vol. 40, No. 2, pp. 426441. https://doi.org/10.1108/PIJPSM-03-2016-0044

[9] Cannavacciuolo, L., Illario,M., Ippolito,A., Ponsiglione, C. (2015), "An activity-based costing approach for detecting inefficiencies of healthcare processes", Business Process Management Journal, Vol. 21, No. 1, pp. 55-79. https://doi.org/10.1108/BPMJ-11-20130144

[10] Khataie, A., H., Bulgak, A., A. (2013), "A cost of quality decision support model for lean manufacturing: activity-based costing application", International Journal of Quality \& Reliability

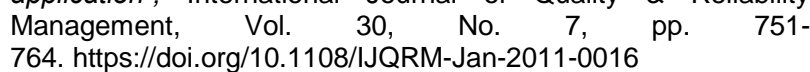

[11] Krumwiede , K., R., Charles, L., S. (2014), "The Use of Activitybased Costing with Competitive Strategies: Impact on Firm Performance, in Marc J. Epstein, John Y. Lee (ed.)", Advances in Management Accounting (Advances in Management Accounting, Vol. 23) Emerald Group Publishing Limited, pp.113 - 148.

[12] Kuethe, T., Morehart, M. (2012), "The Agricultural Resource Management Survey: An information system for production agriculture", Agricultural Finance Review, Vol. 72, No. 2, pp. 191 200. https://doi.org/10.1108/00021461211250429

[13] Lelkes, A.-M., T. (2014), "The Technical Efficiency Portrayed by Duration-Based and Activity-Based Costing Systems, in Marc J. Epstein, John Y. Lee (ed.)", Advances in Management Accounting
(Advances in Management Accounting, Vol. 24) Emerald Group Publishing Limited, pp.61 - 76

[14] Quinn, M. Elafi, O., Mulgrew, M. (2017), "Reasons for not changing to activity-based costing: a survey of Irish firms", PSU Research Review, Vol. 1, No. 1, pp. 6370. https://doi.org/10.1108/PRR-12-2016-0017

[15] Slangen, L.H.G., Suchánek, P., Cornelis van Kooten, G. (2003), "Trust in countries in transition: empirical evidence from agriculture", International Journal of Social Economics, Vol. 30, No. 10, pp. 1095-1109, https://doi.org/10.1108/03068290310492887

[16] Zhang, Y., F., Hoque, Z., Isa, Ch., R. (2015), "The Effects of Organizational Culture and Structure on the Success of ActivityBased Costing Implementation, in Marc J. Epstein, John Y. Lee (ed.)", Advances in Management Accounting (Advances in Management Accounting, Vol. 25) Emerald Group Publishing Limited, pp.229 - 257

[17] Gunasekaran, A., Marri, H.B., Yusuf, Y.Y. (1999), "Application of activity-based costing: some case experiences", Managerial Auditing Journal, Vol. 14, No. 6, pp. 286293. https://doi.org/10.1108/02686909910280217

[18] Kostakis, H., Sarigiannidis, C., Boutsinas, B., Varvakis, K. Tampakas, V. (2008), "Integrating activity-based costing with simulation and data mining", International Journal of Accounting \& Information Management, Vol. 16, No. 1, pp. 2535. https://doi.org/10.1108/18347640810887744

[19] Zakić, V. - Borović, N. (2013), "Application Of Activity-Based Costing In Agricultural Enterprises", AgEcon Search. Research in Agricultural \& Applied Economics, No. 9

[20] Kaszubski, M., A., Ebben,S. (2005), “Using activity-based costing to implement behavioural cost initiatives successfully", Journal of Facilities Management, Vol. 3, No. 2, pp. 184192. https://doi.org/10.1108/14725960510808473

[21] Popesko, B. (2012), "Process cost management methods using Activity Based - Costing. (Procesní rízení nákladu s využitím metódy Activity Based - Costing)", Success - innovation and productivity in contexts No. 2. (Úspěch - produktivita a inovace v souvislostech, No. 2.)

[22] Popesko, B. (2010), "Calculation methodology of Activity-Based Costing in industrial companies. (Metodika aplikace kalkulace Activity-Based Costing v prümyslových firmách)", E\&M Economie and Management, Vol. 13, No. 1, pp. $103-114$.

[23] Popesko, B., Papadaki, Š. Novák, P. (2015), "Cost and reimbursement analysis of selected hospital diagnoses via Activity-Based costing", E\&M Economie and Management, Vol. 18, No. 3, pp. 50-61. http://dx.doi.org/10.15240/tul/001/2015-3005

[24] Ittner, C. D., Lanen, W. N., Larcker, D. F. (2002), "The association between activity-based costing and manufacturing performance", Journal of accounting research, Vol. 40, No. 3, pp. 711726. https://doi.org/10.1111/1475-679X.00068

[25] Dalci, I., Tanis, V., Kosan, L. (2010), "Customer profitability analysis with time-driven activity-based costing: a case study in a hotel", International Journal of Contemporary Hospitality Management, Vol 2, No. 5, pp. 609637. https://doi.org/10.1108/09596111011053774

[26] Langfield-Smith, K., Thorne, H., Hilton, R.W. (1998), Management Accounting: An Australian Perspective, Hong Kong: McGraw-Hill

[27] Foltínová, A. et al. (2011), Cost controlling (Nákladový controlling). Bratislava: Sprint vfra, $450 \mathrm{p}$.

[28] Cohen, S. et al. (2005), "ABC: Adopters, supporters, deniers and unawares", Managerial auditing journal, Vol. 20, No. 9, pp. 9811000. https://doi.org/10.1108/02686900510625325

[29] Altawati, N. et al. (2019), "A Review of Traditional Cost System versus Activity Based Costing Approaches", Advanced science letters, 24: 4688-4694

[30] Alcouffe, S., Maurice, J., Galy, N. (2019), "Is the limited diffusion of management accounting innovations really a paradox? A metaanalysis of the relationship between product diversity and the adoption of Activity-Based Costing", Comptabilite controle audit, Vol. 25, pp.133-164.

[31] Dvoŕáček, J. (2005), "Audit podniku a jeho operaci (Audit of the company and its processes)". Praha: C.H. Beck, 2005. 165 s. ISBN 80-7179-809-6. 